\title{
TIME-ON-MARKET IN CHINESE CONDOMINIUM PRESALES
}

\author{
Xiaorong ZHOU ${ }^{1, *}$, Velma ZAHIROVIC-HERBERT ${ }^{2}$, Karen M. GIBLER ${ }^{3}$ \\ ${ }^{1}$ School of Public Finance and Taxation, Southwestern University of Finance and Economics, Chengdu, Sichuan, China \\ ${ }^{2}$ Department of Financial Planning, Housing and Consumer Economics, University of Georgia, Athens, GA, USA \\ ${ }^{3}$ Department of Real Estate, Georgia State University, Atlanta, GA, USA
}

Received 11 November 2016; accepted 4 September 2017

\begin{abstract}
The condominium presale market is characterized by information asymmetry between the developer and potential buyers. A condominium developer faces conflicting incentives to sell units quickly at a lower price to generate cash and sales momentum versus to hold prices high and endure longer marketing time to maximize revenues and maintain the property's value. We examine the pattern of marketing duration for condominium units offered for presale in a large homogeneous development in Chengdu, China using a Cox proportional hazards model. Results indicate that a patient developer may extract a price premium on units. Diminishing risk to buyers is associated with shorter marketing duration. Time-on-market is also influenced by unit and building size as well as orientation. Market conditions may moderate the speed at which units are sold.
\end{abstract}

Keywords: China, condominiums, housing market, presale, time-on-market.

\section{Introduction}

Imperfect information and information asymmetry characterize real estate markets. Some of the information asymmetry between new house developers/sellers and potential buyers arises from the seller's superior knowledge about the property and the development company that is not shared with the buyers. The potential buyers form expectations about the quality of the construction and the potential for developer default without the ability to fully monitor construction or other developer actions. Such information asymmetry is especially evident in the new condominium presale market common in Asian countries. The developer reveals no information about the financial health of the company or the development while marketing the unfinished product. Financial problems may result in the developer cutting costs on the project to maintain profits. Buyers are purchasing units without the ability to inspect the product or ensure its quality matches that promised by the developer. Thus, information asymmetry is inherent, which creates a moral hazard problem for the buyer. This may, in turn, influence final negotiated prices as well as time-on-market (TOM).

In an environment of such information asymmetry, the seller with superior information would be expected to wait until a buyer willing to pay the seller's reservation price appears rather than to focus on a shorter time-on- market. However, because the developer is dealing with multiple units, the financial stakes are higher than for an individual seller in a random matching situation in determining whether to accept an offer or extend TOM. The conditions surrounding negotiation decisions of a condominium developer differ from a seller of a single house. First, a developer is more like a manufacturer or retailer with an inventory of products to sell. Second, a condominium developer has a finite inventory of goods to sell that will become available at the same time through presale of multiple units in a building. Furthermore, the actions of developers of larger projects with numerous phases have longer repercussions. Condominium construction projects incur large capital costs that accumulate over time until the units are sold, so it is costly to hold unsold units. The cost of continuing to market units may be relatively high compared to the potential additional revenue, encouraging the developer to agree to lower prices to reduce marketing duration. In addition, refusing to agree to lower prices may result in lost sales to competitors and more developers entering the market. On the other hand, if supply is limited in the area, then potential buyers face a time constraint to obtain a unit in the development before they are all sold.

The variability of the units within the condominium may affect marketing duration as measured by TOM.

${ }^{*}$ Corresponding author. E-mail: xrzhou@swufe.edu.cn 
If substantial heterogeneity exists, the preferred units may be sold quickly while the least desirable units may linger. In more homogeneous developments, units are less distinguishable, which should lead to a more uniform marketing duration among units.

Buyers incur more risk by purchasing units early in the presale process. An early purchase means that the buyer forgoes alternative investments with the equity, earns no dividends or rents on the unfinished property, and may incur carrying costs, such as mortgage payments. The risk of default by the developer declines over time as more capital is invested and construction proceeds. As buildings are completed, buyers have greater opportunity to evaluate the quality of construction. Potential buyers can see the early phases of the project physically under construction, providing tangible evidence of the product. Information asymmetry about the project and the risk of developer default are reduced as the development proceeds.

Not all factors affecting TOM are specific to the condominium development. Economic conditions may also play a role. Lower interest rates reduce the cost of buying a house, allowing more buyers to enter the market, but also reduce the developer's carrying costs. If housing prices are expected to trend downward, the developer may agree to lower prices to sell the units as fast as possible before the market slows. If the housing market is expected to improve, then buyers may try to "lock in" prices before they climb while the seller is more inclined to wait for higher prices. If inventory is tight, buyers will want to purchase before available units are taken by other bidders. Thus, characteristics of the development as well as housing market conditions may determine TOM in a condominium presale environment.

Although empirical studies of TOM for owner-occupied housing started as early as the 1970s (Belkin, Hempel, \& McLeavey, 1976), most examine only the resale of singlefamily houses using a random matching model. The presale approach to condominium marketing common in many Asian cities has been attracting more interest from researchers in recent years, but the focus has been on prices and the risk of default. Theoretical studies have modelled presale transactions as forward or futures contracts, options contracts, or with game theory. ${ }^{1}$ This study differs from previous research in its focus on TOM in the presale environment. We examine the pattern of TOM for condominium units offered for presale in several phases of a single large development in Chengdu, China. We examine how TOM varies as the developer offers five phases of the development, each containing one to three buildings. By using data from one large new housing development, we are able

\footnotetext{
1 See Chan, Fang, and Yang (2008), Chan, Wang, and Yang (2012), Chan, Fang, and Yang (2014), Chau, Wong, and Yiu (2003), Choi, Rasmussen, and Davison (2012), Deng and Liu (2009), Edelstein, Liu, and Wu (2012), Fan, Pu, and Ong (2012), Hwang and Quigley (2010), Lai, Wang, and Zhou (2004), Leung, Hui, and Seabrooke (2007b), Wong, Yiu, Tse, and Chau (2006), Yiu, Hui, and Wong (2005), and Yiu, Wong, and Chau (2009).
}

to control for a number of project-specific characteristics because they are nearly identical for all observations. This allows us to focus on factors that are directly observable and to more precisely model TOM. Our results indicate that longer TOM is associated with a price premium. In addition, the unit's physical characteristics (unit and building size as well as orientation), economic and housing market conditions, as well as available inventory in the development influence TOM. The paper is organized as follows. The next section develops the theoretical basis for the paper. Previous related research is summarized before the presale system in China is explained. The model and data are presented in the subsequent section. The results are followed by the conclusion and discussion of implications.

\section{Theory and previous research}

Akerlof (1970) proposes that if asymmetric information exists, supplying lemons is possible. Asymmetric information undermines the direct transfer of information between market participants. Therefore, whoever possesses more or superior information is able to generate rewards from exaggerating the positive qualities of products (Leland \& Pyle, 1977). Moral hazard arises when the actions of one party (the developer, in this case) are unobservable, but pertinent, to the other party (the presale buyer in this case) (Holmstrom, 1979). Gwin and Ong (2000) postulate that developers have an incentive to deviate below announced effort and workmanship to increase their profit margins because buyers cannot observe effort level. Similarly, Farrell (2003) proposes that developers are able to transfer wealth to themselves from their principals in construction projects through the use of actions that are unobservable by the principals. When a developer hides information about the negative aspects of the project, buyers may overestimate the quality of the end product and pay a higher price than would be expected in an efficient market. Ong (1997) shows how presale developers have even greater disincentive to exert effort. Government building codes and inspections, warranties, and reputation effects can moderate the developer's behaviour, but moral hazard still exists.

Preselling unfinished properties transfers some of the market risk from developers to buyers during the construction period. Once buyers sign a purchase contract, they bear risk, both a share of the market risk as well as idiosyncratic risk arising from asymmetric information. Buyers have to rely on the specialist knowledge of the developer to finish the construction work. An inherent asymmetric information problem exists in that the developer is more knowledgeable about the development than the new owners. Because the buyers lack construction knowledge and expertise, they cannot be sure that their interests are best served by the developer in terms of the quality of the work and the timely completion of construction. They also possess limited ability to determine the developer's leverage and solvency (Chan, Fang, \& Yang, 2014). Thus, they have limited information as to the probability 
of the developer completing the condominium in accordance with the terms stipulated in the contract. Studies in China and other countries indicate that consumers should be concerned that problems such as these may arise in condominium presale arrangements. ${ }^{2}$ Yang (2001) reports that weak legal supervision, insufficient protection systems, and local government corruption contribute to poor construction quality, false advertisements, unmet promises, and imperfect contracts, leaving consumers to determine house quality based on their own subjective probabilities. Newspaper articles report Chinese consumer complaints about house quality (Liu, 2007). Media reports indicate that the most common reasons for legal disputes between developers and house buyers in China include delayed delivery, poor construction quality, flawed floor or subdivision plans, and exaggerated floor area. As the project progresses, information asymmetry is reduced as physical construction of the building reduces developer default risk. In addition, if a potential buyer waits to make an offer on a unit in later phases, the completed buildings in the first phases allow a limited opportunity to observe the quality of construction from a distance.

A seller search model is fashioned so that a single seller faces a sequence of randomly arriving buyers. The simplest model assumes a posted price that a buyer either accepts or rejects and the search for a buyer continues; however, this ignores the possibility that the seller will negotiate from the initial offering price. The market clears on both time and price as sellers offering and accepting a lower price also experience a shorter TOM (Han \& Strange, 2015). In this vein, Cubbin (1974) models an individual house seller search model in which the difference between the actual and expected price for a house based on its characteristics is termed the quality adjusted price. The variation in demand in relation to the quality adjusted price is measured in TOM.

Empirical studies based on a random matching model attempting to quantify the relationship between sales price and TOM using resale houses have produced mixed results. ${ }^{3}$ Initial studies that use very small samples find a positive relationship between sales price and TOM. Most relevant to this study, Hui, J. T. Y. Wong, and K. T. Wong (2012a), Hui and Yu (2012b), whose sample of Hong Kong condominium transactions includes a small percentage of presales, observe that the relationship of sales price with TOM depends on market conditions during the time period under study. Rising property prices are associated with shorter TOM as buyers purchase a property as soon as possible because even higher prices are expected in

2 See Leung, Hui, and Seabrooke (2007a, 2007b) and Ong (1999) for discussion of reported problems.

3 See Benefield, Cain, and Johnson (2014) and Sirmans, MacDonald, and Macpherson (2010) for reviews of the literature. Specific studies include An, Cheng, Lin, and Liu (2013), Asabere and Huffman (1993), Kalra and Chan (1994), Kang and Gardner (1989), Miller, Sklarz, and Ordway (1988), and Waller, Brastow, and Johnson (2010). the future. Similarly, Leung, Hui, and Seabrooke (2007b) suggest buyers have an incentive to act early in the presale process to take advantage of the current price when prices are anticipated to increase in a boom market. Ong and Koh (2000) include two house price indices in their study because of the separate but related public and private housing markets. Meanwhile, An, Cheng, Lin, and Liu (2013) assert that in a market where demand is strong and house values appreciate over time, longer TOM can lead to higher expected prices than in a stable market, encouraging a seller to hold out for a higher price.

As for competition, Li (2004) finds that a higher market take up rate among competitors' presale units leads to longer TOM. Because all the units in a building are offered to the market at the same time, the amount of internal competition varies over time. $\mathrm{Li}$ (2004) finds that the number of units in a phase or project is positively related to TOM.

A macroeconomic influence commonly included in TOM studies is mortgage interest rates. Low interest rates reduce the cost of housing and encourage buyers to purchase quickly, especially if rates are expected to rise. Meanwhile, the developer also pays interest on construction loans, so a low interest rate reduces carrying cost and allows the seller to wait longer to find a buyer willing to pay a higher price. Kalra and Chan (1994) find a positive relationship between mortgage rates and TOM as affordability declines in the resale market. $\mathrm{Li}$ (2004) finds a negative relationship in the sale of new condominiums in Singapore. He suggests that the results are due to the reliance on adjustable rate mortgages, which encourages buyers to borrow even when rates are high because they know the rate will adjust down if the prime lending rate declines. He also notes that his study uses data from an atypical time period when mortgage rates did not move in tandem with the prime lending rate, which may bias his results.

Another consideration that is unique to the presale market is that buyers must pay for their units months to years before taking possession. Thus, buyers early in the development process incur higher opportunity cost of holding the presale unit during the construction period. This should encourage buyers to wait and then more quickly purchase units offered for sale closer to the project completion date. Li's (2004) results do not support this assertion; however, he attributes this to his sample in which all the units have long waiting periods.

Housing characteristics also influence TOM. Li (2004) finds that physical characteristics contribute to TOM for new condominiums. Smaller units on higher floors that face east or west experience longer TOM in Singapore. Although Ong and Koh (2000) consider condominiums resales instead of new unit sales in Singapore, their results indicate units on low floors bring lower prices and take longer to sell, but units on high floors also have longer TOM, which they attribute to the higher prices for such units.

A longer series of studies has established the common physical characteristics that contribute to the price of condominiums. These characteristics include size, floor within a multi-story building, and view (Hui et al., 2012a; 
Ong \& Koh, 2000; Yang, 2001; Wu, Deng, \& Liu, 2014). Buyers are expected to pay higher prices for larger units. The price effect of building height, floor location, and window direction appears ambiguous. High-rise buildings may represent prestige and offer better views; however, taller buildings also create higher population density that may result in overcrowding (Wong, Chau, Yau, \& Cheung, 2011). Higher floors may provide better views, but with slower elevator access. Living on the top floor of a building ensures that no neighbours are located above the unit, but noisy equipment may be located on the roof. The ground floor provides easy access, but also loss of privacy. West and south facing units suffer summer heat, but north facing units are darker in winter.

Most studies that examine the information asymmetry and moral hazard problems inherent in presale contracts focus on the effect on price rather than TOM. Fan, Pu, and Ong (2012) suggest that presales may be viewed as a contract for hedging against house price risk and develop a utility indifference model for pricing presale transactions. They suggest that even if the sellers and buyers share the same beliefs about future house prices and risk that a differential in market power will influence whether the final negotiated price is above or below the expected risk-neutral forward price. While higher expected growth in value and decreased volatility should lead to higher presale prices, the effects of changes in interest rates and the forward contract period on presale prices are ambiguous.

Chan, Fang, and Yang (2008), Chan, Wang, and Yang (2012), Chan, Fang, and Yang (2014) employ a gametheoretic model assuming no asymmetric information about the developer's default and abandonment risk to examine the negotiation of presale prices and the exercise of the developer's option to abandon a project. Developers should be willing to agree to lower prices early in the presale process because of risk sharing with the buyer; however, their model indicates that the lower the presale prices in the first phase of construction, the higher the developer's incentive to abandon construction. The abandonment incentive is moderated depending on the reputation costs associated with defaulting on the project. Meanwhile, if buyers are required to make a large down payment, then risk is shifted to the buyer, reducing the price they are willing to pay and discouraging them from purchasing early in the process. Because buyers do not have perfect information about future values, if property prices are expected to rise, they have a conflicting incentive to purchase early in the presale process before prices rise beyond their reach. In addition, market conditions influence the probability of developer abandoning a project. Increasing construction costs and competition that reduce profits make the developer more likely to exercise the abandonment option.

Edelstein, Liu, and Wu (2012) contribute a theoretical model that utilizes a microeconomic market equilibrium framework to explore how presales are used to mitigate risks of market value changes and default. They hypothesize that if developers expect larger house price growth, they will hold onto inventory longer. A higher price risk is associated with a higher presale premium and more presale transactions. They model the moral hazard problem so that as the risk of developer default increases, the volume of transactions shrinks. While they do not model the relationship, the researchers suggest the interaction and risk sharing implied by third-party financing should be considered.

In contrast, Lai, Wang, and Zhou (2004) use a real options approach to model the presale benefits to the developer; however, the presale practices in the Chinese market have changed since the development of their model, which modifies their assumptions about the timing of purchase payments and default options.

Ong (1999) builds upon his moral hazard model that purports that developers have less incentive to provide quality workmanship in presale arrangement (Ong, 1997) to develop an adverse selection model to show how preselling can be detrimental to buyers because they are unable to differentiate good developers from bad developers when they commit to purchasing unfinished properties, thereby bearing the risk of failure, negative interim shocks, and lower construction quality. Chau, Wong, and Yiu (2003) refute Ong's findings, using an ordinary least squares regression to examine presales and resales in Hong Kong, attributing the difference in prices between units constructed by two developers both in the presale and resale market to the quality of the units, which buyers estimated based on the developers' reputations (one a listed blue chip company with a large portfolio and the other a smaller private company). Chau, Wong, and Yiu (2007) conclude that this indicates that developers do not have an incentive to deliver low quality products despite buyers' inability to monitor construction. Meanwhile, Leung (2010) builds upon Leung et al. (2007b) to consider the moral hazard problem and constructs a forward-spot index tracking model to compare prices in the Hong Kong presale and spot market, finding that presale transaction prices reflect a discount related to the interest rate at the time of presale and the length of the construction time-lag to compensate for the cost of capital incurred by the buyer within the forward contract. However, they also find evidence that presale prices can be higher than spot market prices due to hidden presale risks. Yang (2001) uses a selfinsurance model to include risk of construction quality in a hedonic model via a proxy variable of construction company prestige, finding a significant coefficient when tested on Beijing house sales. This focus on price ignores TOM in presale markets.

\section{Presale practice in China}

The most common sales method for new residential condominiums in China is presale. Presales also occur in other countries, including Australia, Canada, Malaysia, Singapore, South Korea, Taiwan, the UK, and the US. In China, the developer often sets up a showroom offsite for potential buyers to see models and floor plans before 
construction or presales begin. Salespeople employed by the developer staff the showroom and work with potential buyers. The developer follows an approved construction schedule and is required to invest at least 25 percent of the total building cost to obtain permission to offer units for presale. Once the local government issues presale consent, then the developer can offer units for sale and sign contracts with buyers, often one to two years before completion and delivery (Deng \& Liu, 2009). The developer usually offers all the units in one or more buildings for presale on the same date. Price lists may not be available and information about offering prices and previous sales is selectively released by sales agents. The benefits of the presale method to the developer include reduced uncertainty about demand, the receipt of payments from buyers earlier in the development process, and reduced inventory costs (Lai et al., 2004). While the developer in some countries may adjust the design of latter phases of construction in response to sales in early phases (Hua, Chang, \& Hsieh, 2001), the approval and permitting process in China requires the developer to submit final plans for the entire development before starting construction. Once development has commenced, adjustments are only allowed under special circumstances.

A presale contract gives the condominium buyer the right to purchase the unit at a negotiated price using a prearranged payment schedule. The structure of Chinese presale arrangements has evolved over time so that buyers now sign a purchase contract to lock in the price for a specific unit and then pay the full presale price (either in cash or by use of a down payment of at least 30 percent plus mortgage funds) or the developer may agree to finance the purchase price directly through two or three instalment payments over three to six months. Once the contract is signed and payment received, the buyer takes title to the unit and begins repayment of any mortgage, but does not take possession of the unit until all phases of the project are completed and approval is given by the local authority. Thus, buyers face the risk of a developer abandoning the project before completion (Chan et al., 2012, 2014) or delivering a product whose quality does not meet expectations (Chau et al., 2007). To protect buyers, developers are required to hire a private supervision company. The third party supervises during the construction process to ensure the developer follows the subdivision plan and construction code. Once the construction is finished, a government-initiated inspection process is followed. If the project passes the inspection, the developer can offer the units to the buyers for occupancy. If the developer delivers an unsatisfactory product, the buyers can pursue a refund or financial compensation. ${ }^{4}$ If the developer defaults and abandons the project (usually due to financial distress), the buyers have the right to pursue a refund of all the

\footnotetext{
4 Such problems have occurred in Chengdu. For example, in 2006, the "Shuangnan Yingxiang" complex was delivered to its presale buyers without the promised green areas and swimming pool.
}

money paid to the developer. (The buyer is still obligated to repay any third-party mortgage.) These are the conditions under which this study takes place.

\section{Method}

We adopt a 2-step method to solve the simultaneity problem between house price and TOM. In the first step, shown in Eq. (1), we regress the selling price $\left(P_{S}\right)$ of each sold condominium unit on its property attributes while controlling for method of financing and housing market conditions.

$$
\begin{aligned}
& \text { LnP } P_{S}=\alpha+\beta_{1} \text { HIGHRISE }+\beta_{2} \text { SIZE }+\beta_{3} \text { TOP }+ \\
& \beta_{4} \text { BOTTOM }+\beta_{5} \text { WEST }+\beta_{6} \text { SOUTH }+ \\
& \beta_{7} \text { FINANCE }+\beta_{8} \text { INTERESTRATE }+ \\
& \beta_{9} \text { PRICEINDEX }+\beta_{10} \text { INVENTORY }- \text { TO }- \text { SALES }+ \\
& \beta_{11} \text { PHASE } 1+\beta_{12} \text { PHASE } 2+\beta_{13} \text { PHASE } 4+\beta_{14} \text { PHASE }+\varepsilon
\end{aligned}
$$

The price of a housing unit is a function of the characteristics of the dwelling, its neighbourhood, and access to services and facilities. Because this analysis uses observations from one large new condominium development, the site, amenities, access, and neighbourhood characteristics are uniform across all units. Therefore, typical controls for location, transportation access, and neighbourhood characteristics are unnecessary. Similarly, all of the housing units are new, of similar quality, and vary little in terms of unit finishes or amenities. Therefore, no atypicality measure (Haurin, 1988) is required. Some physical characteristics can vary among units within the development and have been found to be significantly related to condominium prices in previous studies, so they are included in the equation. The variable descriptions are provided in Table 1. HIGHRISE indicates whether the unit is located in a high-rise building of 18 floors or a mid-rise building containing 11 floors. SIZE is unit size in square metres. ${ }^{5}$ TOP and BOTTOM represent the location within the building, bottom floor or top floor (which is floor 11 in mid-rise and 18 in high-rise buildings). VIEW indicates which direction the unit faces and is represented by a series of dummy variables (WEST, SOUTH).

Method of payment, FINANCE, can be a one-time cash payment or financed, which includes the options of a down payment and instalment payments via a plan provided by the developer or a down payment plus mortgage payments arranged through a bank. ${ }^{6}$ Both methods of financing delay the developer's receipt of the full purchase price, so developers sometimes offer cash discounts. INTERESTRATE represents the interest rate on a five-year

\footnotetext{
5 The units vary little in room configuration, so the number of bedrooms and bathrooms is highly correlated with SIZE. Therefore, these variables are excluded from the model.

6 The mortgage market is highly regulated by the government in China with little variation allowed in down payments or interest rates. Thus, mortgage terms available to buyers are standardized.
} 
adjustable rate mortgage during the month of sale to account for the cost of financing. PRICEINDEX accounts for housing market conditions in terms of change in average sales price per square meter for houses in Chengdu in the month prior to the sale, the monthly house price index for Chengdu reported by the National Bureau of Statistics of China. INVENTORY-TO-SALES is a measure of the stock of units available for presale in all buildings in the subdivision at the end of the month prior to the sale of the subject unit divided by the number of units sold in the current month. This variable is a variation on Li's (2004) project size and competitors' take-up rate variables, providing an indication of the project's inventory, sales momentum and internal competition among units in the subdivision. Little outside competition was present in the immediate neighbourhood during construction of the subject subdivision. The PHASE in which a unit is located within the subdivision is indicated by a series of dummy variables with phase 3 as the reference category.

The coefficients produced by the hedonic price equation allow us to predict how much a unit would be predicted to sell for in this market based on its characteristics. Thus, we estimate the predicted selling price $\left(P_{E}\right)$, which is the estimated value of the unit as shown in Eq. (2):
$\operatorname{LnP} P_{E}=\alpha+\beta_{1}$ HIGHRISE $+\beta_{2}$ SIZE $+\beta_{3}$ TOP +

$\beta_{4}$ BOTTOM $+\beta_{5}$ WEST $+\beta_{6}$ SOUTH +

$\beta_{7}$ FINANCE $+\beta_{8}$ INTERESTRATE $+\beta_{9}$ PRICEINDEX +

$\beta_{10}$ INVENTORY - TO $-S A L E S+\beta_{11}$ PHASE $1+$

$\beta_{12}$ PHASE $2+\beta_{13}$ PHASE $4+\beta_{14}$ PHASE 5

Individual buyers may negotiate a price that is higher or lower than this expected price, with a positive amount indicating the seller obtained a price premium on that unit and a negative amount indicating a price discount. Hui and Yu, (2012b) construct a dummy variable (PPA) to measure whether there is a difference in condominium list and sale prices, including some presales. In Hui et al. (2012a), they develop an above market price variable that measures the difference between the log of list price and the log of expected sales price that is calculated using only housing characteristics. We calculate a degree of overpayment variable using the property's observed sales price and the predicted sales price from Eq. (2) that includes both housing attributes and market condition variables. The resulting measure (OVERPAYMENTRATIO $\left.=P_{S} / P_{E}\right)$ which takes on values greater than 1 when a unit sells at

Table 1. Variable descriptions

\begin{tabular}{|c|c|c|}
\hline Variable name & Description & $\begin{array}{l}\text { Expected } \\
\text { relationship } \\
\text { with TOM }\end{array}$ \\
\hline TOM & $\begin{array}{l}\text { Time-on market; number of days starting when the developer offered the } \\
\text { condominium as available for presale through the date a contract for purchase/sale of } \\
\text { the unit was signed }\end{array}$ & - \\
\hline HIGHRISE & Height of building: $1=18$ floors; $0=11$ floors & Inconclusive \\
\hline SIZE & Area in the unit in square meters & Positive \\
\hline TOP & $1=$ unit located on top floor; 0 otherwise (18 in some buildings; 11 in others) & Inconclusive \\
\hline ВОТTOM & $1=$ unit located on bottom floor; 0 otherwise & Inconclusive \\
\hline WEST & $1=$ unit faces west; 0 otherwise & Positive \\
\hline SOUTH & $1=$ unit faces south; 0 otherwise & Inconclusive \\
\hline FINANCE & Method of payment: $1=$ cash; 0 otherwise & Negative \\
\hline OVERPAYMENTRATIO & $\mathrm{P}_{\mathrm{S}} / \mathrm{P}_{\mathrm{E}}$ where $\mathrm{P}_{\mathrm{S}}=$ sales price in Yuan and $\mathrm{P}_{\mathrm{E}}=$ estimated sales price & Positive \\
\hline INTERESTRATE & Interest rate on 5-year adjustable rate mortgage during month of sale & Inconclusive \\
\hline PRICEINDEX & $\begin{array}{l}\text { Change in average sales price per square meter in Chengdu in month prior to sale } \\
\text { from the monthly house price index for Chengdu reported by the National Bureau of } \\
\text { Statistics of China }\end{array}$ & Inconclusive \\
\hline INVENTORY-TO-SALES & $\begin{array}{l}\text { Stock of units available for presale in the development at the beginning of the month } \\
\text { of sale / sales during the month }\end{array}$ & Inconclusive \\
\hline PHASE1 & $1=$ unit in phase 1 of subdivision; 0 otherwise & Positive \\
\hline PHASE2 & $2=$ unit in phase 2 of subdivision; 0 otherwise & Positive \\
\hline PHASE4 & $4=$ unit in phase 4 of subdivision; 0 otherwise & Negative \\
\hline PHASE5 & $5=$ unit in phase 5 of subdivision; 0 otherwise & Negative \\
\hline
\end{tabular}


a premium and values less than 1 when a unit sells at a discount from the estimated market value.

To examine the variable of interest, TOM, we employ a Cox (1972) proportional hazards model to test how property characteristics, changing housing market conditions, and degree of overpayment affect TOM during the presale period. If $T$ represents the length of time a house is on the market, then the hazard rate measures the likelihood that a condominium will be sold at time $t$ given that it has not been sold before time $t$. We identify the vectors of explanatory variables $X$ and $Z$, where $X$ represents housing attributes and $Z$ represents housing market condition variables. The hazard model is then as shown in Eq. (3):

$$
h(t)=h_{0}(t) \exp \left(X_{i} \delta+Z_{i} \gamma\right),
$$

where: $h_{0}(t)$ is the baseline hazard function and $\delta$ represents proportional hazard regression coefficients. The model uses a likelihood approach to estimate the vector of coefficients from the hazard function. A significant coefficient indicates that the explanatory variable affects the hazard rate. A likelihood ratio test can be used to determine if the coefficients are significantly different from zero. We can further estimate the hazard ratio to assess the importance of explanatory variables.

The empirical model states that the likelihood that a housing unit will be sold at a given time is a function of housing unit characteristics, degree of overpayment, method of financing, mortgage interest rates, and housing market conditions. TOM is the number of days starting when the developer offers the condominium as available for presale through the date a contract for purchase/sale of the unit was signed (if a unit sold on the same date of the announcement, $T O M=1$ ). The same housing attribute variables and method of payment variables are included as in equation 1.

Larger units may take longer to sell for two reasons. First, because of their higher price, they may create an affordability problem for many buyers. Second, they require more capital investment, increasing financial risk for the buyer. Consistent with $\mathrm{Li}$ (2004), we expect smaller units to experience shorter TOM. Also consistent with Li (2004), we expect units that face WEST so they experience the heat of the afternoon to take longer to sell. Facing SOUTH can be both positive and negative, so the relationship with TOM is uncertain. Previous research (Li, 2004; Ong et al., 2000) has produced contradictory results regarding the relationship between the floor on which a unit is located and its TOM, so we do not have a prediction about the relationship between BOTTOM and TOP floor locations and TOM. Similarly, because there are both advantages and disadvantages to living in a high-rise building, the effect of height is uncertain. Because purchasing early in the development period increases the time over which the buyer has invested capital without receiving rents or interest as well as a longer wait to observe construction to reduce information asymmetry, longer TOM would be expected during early phases of construction.
$Z$ includes housing market condition variables consistent with Hui et al. (2012a), Hui and Yu (2012b). If prices are anticipated to increase, buyers have an incentive to purchase early (Leung et al., 2007b) while developers have an incentive to hold inventory longer (An et al., 2013; Edelstein et al., 2012); thus, the relationship between average house prices in the area (PRICEINDEX) and TOM is uncertain. Lower interest rates (INTERESTRATE) reduce the cost of buying a house and lowers the carrying cost for the buyer during the construction period, allowing more buyers to enter the market, and may lead to shorter TOM, consistent with Kalra and Chan (1994) if the buyer's cost savings dominate the seller's; or, if the seller's cost savings dominate the buyer's, we will observe a longer TOM consistent with Li (2004). While Edelstein et al. (2012) suggest the risk sharing implied by third-party financing should be considered, they do not model the relationship. A seller negotiating with a buyer who is paying cash can come to an agreements faster than when a third-party is involved and a seller is more likely to prefer a cash buyer to providing financing, possibly resulting in shorter TOM. INVENTORY-TO-SALES indicates whether a new phase offered for presale attracts buyers at the same rate as the previous phase in that the introduction of a new phase would increase the numerator, but if sales rise at the same rate, then there would be a corresponding increase in the denominator. This allows us to look more closely at how TOM varies as the developer introduces each phase of the development, one to three buildings at a time. An et al. (2013) assert that in a market where demand is strong, sellers are encouraged to hold out for a higher price. Li (2004) finds that a larger number of units in a phase and a higher market take up rate among competitors' units in the previous quarter lead to longer TOM. Because our measure of momentum is tied to the number of units in each phase and constructed with data only from the development under study, the relationship between the ratio and TOM is uncertain.

OVERPAYMENTRATIO is added as an explanatory variable in the TOM model. Consistent with the general literature (Cubbin, 1974), we anticipate that it will take longer to find buyers willing to pay a higher price for units with the same attributes. The seller may need to offer a discount from market prices to encourage early sales of those same units when risk to buyers is highest.

\section{Data}

The data for this study come from the sale of new condominiums in a development in Chengdu, China. Because of the large number of condominiums constructed in recent years, new units account for more than one-half of the floor area of all private housing units sold in China (Wu et al., 2014). Chengdu is representative of the national housing market with an average new condominium price close to the national mean (Deng, Li, \& Ye, 2012). Largescale condominium developments that offer relatively homogeneous units like the one used in this study dominate 
Table 2. Variable summary statistics

\begin{tabular}{|l|c|c|c|c|}
\hline \multicolumn{1}{|c|}{ Variable } & Min & Max & Mean & Std. Dev \\
\hline TOM & 1.00 & 305.00 & 45.01 & 0.76 \\
\hline HIGHRISE & 0.00 & 1.00 & 86.52 & 0.43 \\
\hline SIZE & 46.70 & 133.26 & 0.07 & 0.25 \\
\hline TOP & 0.00 & 1.00 & 0.04 & 0.19 \\
\hline BOTTOM & 0.00 & 1.00 & 0.19 & 0.39 \\
\hline WEST & 0.00 & 1.00 & 0.11 & 0.43 \\
\hline SOUTH & 0.00 & 1.00 & 1.00 & 0.06 \\
\hline FINANCE & 0.00 & 1.00 & 6.10 & 0.23 \\
\hline OVERPAYMENTRATIO & 0.71 & 1.19 & 0.30 & 0.35 \\
\hline INTERESTRATE & 5.94 & 7.05 & 2.52 & 1.26 \\
\hline PRICEINDEX & -0.20 & 1.00 & 354955.60 & 112289.14 \\
\hline INVENTORY-TO-SALES & 178515.00 & 691909.00 & & \\
\hline SALES PRICE (PS) & & & & 0.50 \\
\hline
\end{tabular}

Note: Number of observations $(\mathrm{n})=934$.

the new house market in this city. It was an active market during the time the data were collected (almost 20 million square metres of new housing space started construction in 2010 while 13 million square metres were completed) (National Bureau of Statistics of China, 2011).

The sales from one typical development located in Wenjiang district in Chengdu comprise the sample. This local developer entered the Chengdu market in 2004 and developed two housing complexes in the area before the one under study. So far, there are no public records of default or consumer complaints filed against this developer. The development is of average size for a development in Chengdu. The subdivision that provides the observations for this study contains 1,180 1-, 2-, and 3-bedroom units in 10 buildings. Buildings contain either 11 or 18 stories. All the units within the development share the same location and neighbourhood attributes as well as many building characteristics such as materials. They differ only in terms of size, floor level, and the direction that their windows face, reducing the need for controls for neighbourhood and other external differential effects on house prices. Of the 1,180 units in this Subdivision, 1,145 sold during the study period. Removal of observations with missing values on variables in the model and three TOM outliers produces 934 transactions for the analysis. While TOM among all units sold ranged from 1 to 305 days with an average of 45 days, as is shown in Table 2, 97\% of the units from all phases sold within 204 days, the time period the last phase was available to the market. A majority of the units are located in high-rise buildings. The average floor area is just over 86 square metres and the average sales price is $354,955.60$ Yuan.
The site plan, building design, and construction schedule for all the buildings in the subdivision were approved prior to commencing development. Once the developer had invested 25 percent of the construction cost in a phase, the units in that phase could be offered for presale. The buildings were offered for presale in five stages. As shown in Table 3, two buildings, one high-rise and one mid-rise, were offered for presale on December 12, 2009, which produced 246 transactions. The second phase consists of three buildings offered on July 17, 2010. Just one high-rise building was offered as phase 3 . Phase 4 , was offered six weeks later. The last two mid-rise buildings were offered for presale on December 27, 2010. All units were released for occupancy in January 2012. Thus, the time between the first phase of the subdivision being offered for sale to the last phase entering the market was just over one year, which limits the effects of changes in market and economic conditions that could affect the terms of the sales, although interest rates and market house prices were generally rising over the study period, so are included in the model. This also means that the data reflects market behaviour only in the growth phase of the real estate cycle. The transactions included in the study took place December 12, 2009 through July 2011, just over six months after the last phase was offered for sale and six months before the owners took possession; $97 \%$ of all the units in the subdivision were sold during this time period.

Mean price varies by phase in line with the average size of units in each phase. Phases 2 and 3 contain smaller units, on average (more 1-bedroom units), while phases 4 and 5 (the last phases) contain larger units, on average (more 3-bedroom units). Thus, the development is 
Table 3. Phase characteristics

\begin{tabular}{|c|c|c|c|c|c|c|c|}
\hline \multirow{2}{*}{ Phase } & \multirow{2}{*}{$\begin{array}{l}\text { Date offered } \\
\text { for presale }\end{array}$} & \multicolumn{2}{|c|}{ Number of buildings } & \multirow{2}{*}{$\begin{array}{l}\text { Number of } \\
\text { units sold }\end{array}$} & \multirow{2}{*}{$\begin{array}{c}\text { Unit } \\
\text { average area } \\
\text { (sq.m.) }\end{array}$} & \multirow{2}{*}{$\begin{array}{c}\text { Unit average } \\
\text { selling price } \\
\text { (Yuan) }\end{array}$} & \multirow{2}{*}{$\begin{array}{c}\text { Unit } \\
\text { average } \\
\text { TOM } \\
\text { (days) }\end{array}$} \\
\hline & & High-rise & Mid-rise & & & & \\
\hline 1 & $12-12-2009$ & 1 & 1 & 246 & 87.68 & 335314.24 & 73.11 \\
\hline 2 & $17-7-2010$ & 2 & 1 & 271 & 76.95 & 301994.97 & 24.39 \\
\hline 3 & $11-9-2010$ & 1 & 0 & 142 & 61.04 & 255293.45 & 32.58 \\
\hline 4 & $23-10-2010$ & 1 & 1 & 175 & 96.52 & 431049.90 & 41.74 \\
\hline 5 & $27-12-2010$ & 0 & 2 & 100 & 128.32 & 555151.90 & 55.15 \\
\hline
\end{tabular}

Note: High-rise contains 18 stories and mid-rise contains 11 stories.

characterized by the introduction first of many average size units, then smaller units, and, lastly, more large units. The average size of a unit in the development is 86.5 square metres, but ranges from a mean of 61.0 square metres in phase 3 to 128.3 square metres in phase 5 . The units in phase 1 experienced the longest time, on average, between offering and sale with a mean TOM of 73.11 days while the units in phase 2 sold the fastest, on average, at a mean of 24.39 days, with TOM growing longer again in phases 3 through 5 at 32.58 to 55.15 days. The highest number of sales occur during the first month a phase is offered for presale, followed by slowing sales, but with smaller peaks again during the second, third or fourth month after the offering. Although the developer did introduce larger units in latter phases, because the plan for all the units had to be submitted and approved before start of construction, the larger units were planned from the start and were not added as a response to the developer obtaining information in the first two phases that was used to redesign units in later phases.

\section{Results}

The selling price model has an $\mathrm{R}^{2}$ of $96.3 \%$. As expected, larger units sell for higher prices. As shown in Table 4, whether a unit is located in a high-rise building, the unit's floor, and whether it faces south are significant, indicating units in 18-story buildings as well as on the top or bottom floor sell for higher prices than those in mid-rise buildings or middle floors while those units facing south sell at a premium to those facing other directions, similar coefficients as those found in another Chengdu study (Zhou, Zahirovic-Herbert, \& Gibler, 2015). The prestige and views afforded by a high-rise building appear to outweigh the disadvantages of more residents. Buyers appear to be willing to pay more for the views and lack of upstairs neighbours afforded by the top floor as well as the ease of access of the ground floor. The natural sunlight afforded by southern exposure is also valued. In addition, prices vary by phase with lower prices in the early phases and higher prices in phase 4. Cash discounts are evident while higher interest rates are positively related to price. Inter-
Table 4. Price estimation results

\begin{tabular}{|l|c|c|c|c|}
\hline \multicolumn{1}{|c|}{ Variable } & Coefficient & t-statistic & Tolerance & VIF \\
\hline HIGHRISE & 0.112 & $15.083^{\star * *}$ & 0.377 & 2.650 \\
\hline SIZE & 0.013 & $104.170^{\star * *}$ & 0.287 & 3.480 \\
\hline TOP & 0.052 & $5.962^{\star * *}$ & 0.984 & 1.016 \\
\hline BOTTOM & 0.062 & $5.835^{\star * *}$ & 0.930 & 1.075 \\
\hline WEST & 0.000 & -0.038 & 0.701 & 1.427 \\
\hline SOUTH & 0.048 & $7.271^{\star * *}$ & 0.626 & 1.597 \\
\hline FINANCE & -0.027 & $-5.002^{\star * *}$ & 0.942 & 1.062 \\
\hline INTERESTRATE & 0.071 & $3.356^{\star * *}$ & 0.240 & 4.165 \\
\hline PRICEINDEX & -0.012 & -1.116 & 0.538 & 1.860 \\
\hline $\begin{array}{l}\text { INVENTORY- } \\
\text { TO-SALES }\end{array}$ & 0.003 & 1.344 & 0.842 & 1.188 \\
\hline PHASE1 & -0.022 & $-3.003^{* * *}$ & 0.287 & 3.487 \\
\hline PHASE2 & -0.043 & $-6.525^{\star * *}$ & 0.319 & 3.139 \\
\hline PHASE4 & 0.063 & $7.846^{* * *}$ & 0.265 & 3.777 \\
\hline PHASE5 & 0.010 & 0.568 & 0.223 & 4.479 \\
\hline Constant & 11.088 & $86.221^{\star * *}$ & & \\
\hline Adjusted R & 0.963 & & & \\
\hline
\end{tabular}

Notes: Number of observations 934 . This exhibit presents estimates from the regression model with observed sales price $\left(\mathrm{P}_{\mathrm{S}}\right)$ as dependent variable. Tolerance and variance inflation factor (VIF) statistics are used to test for multicollinearity. ${ }^{*},{ }^{* *}$, and ${ }^{* * *}$ represent significance at the $10 \%$, $5 \%$, and $1 \%$ level, respectively.

est rates on five-year adjustable mortgages were generally rising during the study period (from $5.94 \%$ to $7.05 \%$ ). In addition, the developer was paying higher interest rates on construction borrowing, raising the cost of units, which may be passed along to buyers.

Table 5 presents the results from the Cox proportional hazards model that is the focus of our study on TOM. With covariates, the $-2 \log$ likelihood function value is 10 258.002 , while without covariates the value is 10982.630 . The model is significant at the $1 \%$ level. In this model, the hazard is sale. Thus, the coefficients presented are the relative likelihood of a unit selling, which means a positive coefficient indicates shorter TOM. The hazard ratio in the last column measure the sensitivity of ending market- 
Table 5. Time-on-market estimation results

\begin{tabular}{|l|c|c|c|c|}
\hline \multicolumn{1}{|c|}{ Variable } & $\beta$ & SE & Wald & $\operatorname{Exp}(\beta)$ \\
\hline HIGHRISE & -0.620 & 0.139 & $19.978^{* * *}$ & 0.538 \\
\hline SIZE & -0.014 & 0.002 & $29.532^{* * *}$ & 0.987 \\
\hline TOP & -0.056 & 0.133 & 0.175 & 0.946 \\
\hline BOTTOM & -0.148 & 0.177 & 0.703 & 0.862 \\
\hline WEST & -0.776 & 0.109 & $50.842^{* * *}$ & 0.460 \\
\hline SOUTH & 0.333 & 0.141 & $5.609^{* *}$ & 1.395 \\
\hline FINANCE & -0.065 & 0.079 & 0.666 & 0.937 \\
\hline INTERESTRATE & -7.552 & 0.386 & $383.565^{* * *}$ & 0.001 \\
\hline PRICEINDEX & -0.569 & 0.132 & $18.636^{* * *}$ & 0.566 \\
\hline INVENTORY-TO-SALES & -0.044 & 0.025 & $3.132^{\star}$ & 0.957 \\
\hline PHASE1 & -2.257 & 0.172 & $172.219^{* * *}$ & 0.105 \\
\hline PHASE2 & -1.210 & 0.144 & $70.418^{* * *}$ & 0.298 \\
\hline PHASE4 & 1.123 & 0.180 & $38.924^{* * *}$ & 3.073 \\
\hline PHASE5 & 2.792 & 0.243 & $131.789^{* * *}$ & 16.318 \\
\hline OVERPAYMENT RATIO & -4.140 & 0.524 & $62.311^{* * *}$ & 0.016 \\
\hline & 10258.002 & & & \\
\hline
\end{tabular}

Notes: Number of observations 934. This exhibit presents estimates from the Cox proportional hazards model with time-on-market (TOM) as dependent variable. ${ }^{\star},{ }^{*}$, and ${ }^{\star * *}$ represent significance at the $10 \%, 5 \%$, and $1 \%$ level, respectively.

ing period (sale) to changes in an independent variable. The results indicate that longer TOM is associated with the seller achieving a higher price for an individual unit relative to the price predicted based on the unit's physical characteristics and market conditions at the time of sale. If the ratio of negotiated sales price to expected sales price (OVERPAYMENTRATIO) increases by one unit, the condominium is $414 \%$ less likely to sell. With a mean overpayment ratio of 1.0, the hazard ratio of 0.016 indicates that a unit selling for $100 \%$ or 2 times more than the predicted value of a unit is $98 \%$ less likely to sell than a unit selling at its estimated value. So a unit selling for $10 \%$ more than its estimated value is $9.8 \%$ less likely to sell than a similar unit selling at a price equal to its estimated market value.

Examination of the unit characteristics indicate that smaller units sell faster than larger units (measured by area in square metres). A unit that is 1 square metre smaller than another unit is $1.4 \%$ more likely to sell on a given day. The hazard ratio of 0.987 indicates that a unit containing 87.52 square metres is $98.7 \%$ as likely or approximately $1 \%$ less likely to sell as the average unit of 86.52 square metres. A unit that contains 97.52 square metres (10 square metres larger than average) is $13 \%$ less likely to sell on a given day. Units facing west are the slowest to sell with a $78 \%$ lower probability than those facing east or north and those facing south sell the fastest with a 33\% higher probability of sale on a given day than those facing east or north. Thus, the direction a unit faces has substantial influence on TOM. We find that condominiums in mid-rise buildings (11 floors) sell faster than units in high-rise buildings. Location in a high-rise reduces probability of sale relative to a mid-rise building on a given day by $62 \%$. Location on the top or bottom floor has no significant influence on TOM. TOM varies with the phases of the development with units in later phases experiencing shorter TOM than units of similar size and location in earlier phases.

Whether a buyer pays cash or uses a mortgage or instalment plan to finance the purchase has no significant influence on the time it takes for the seller to agree to a contract with a buyer for a particular unit; however, there is evidence of the seller offering a cash discount. Market conditions are associated with changing TOM. When interest rates are lower, units tend to sell faster. If five-year adjustable rate mortgage rates increase by $1 \%$, the likelihood of units selling is reduced by $755 \%$. If the interest rate rises 50 basis points to $6.6 \%$ from the study period average of $6.1 \%$, a condominium is .002 times as likely to sell. Thus, sales are interest rate sensitive. Rising general housing prices in the area are associated with longer TOM for units in the development. A one-unit increase in the price index based on average sales price per square metre in Chengdu in the month prior to sale results in a 
$57 \%$ reduction of the likelihood of selling a unit. A higher project INVENTORY-TO-SALES ratio is associated with a longer TOM, but is only significant at the $10 \%$ level. Thus, when additional units are being offered quicker than the sales rate, it will take longer for the newly offered units to sell.

Thus, the results provide support for a generally positive relationship between the developer achieving a higher price for a given unit with longer TOM in the condominium presale market, similar to results in most studies of the relationship between sales price and TOM in resale markets.

Units in high-rise buildings take longer to sell, but the developer may receive a premium for units in these buildings. The evidence suggests that west facing units are least desirable because they endure longer TOM, as predicted, yet do not command a price premium. South facing units sell faster with a price premium, indicating the positive aspects of southern exposure in the winter outweigh the heat in the summer.

The importance of affordability is evident in that buyers quickly purchase smaller units as predicted. Developers are more likely to sell units quickly when interest rates are low, similar to Kalra and Chan (1994), and are less likely to sell quickly when prices are rising in the market. The interest rate relationship also highlights the importance of affordability. Buyers may try to lock-in a low initial interest rate, expecting further increases. However, as prices rise, sellers may become more patient, waiting for buyers who will pay more as competitive developments' prices rise as well as suggested by An et al. (2013) and Li (2004). If prices are rising faster than income, then the buyers may be unable to purchase units due to lack of affordability, as suggested by Gustavsson and Vahtola (2014).

The reduction in TOM for similar units in latter phases of the development, as predicted, suggests a response to the reduction in risk to the buyer. As the developer invests more in the property, the risk of default declines. In addition, as improvements to the site become visible, the potential buyer can see some of the tangible product and can better evaluate whether the development matches what the promotion promises. Purchasing in the latter phases also means the buyer incurs lower carrying costs.

\section{Conclusion}

Information asymmetry characterizes all real estate markets, but is exacerbated by the nature of the condominium presale process. Developers, by definition, have greater knowledge about the property, its quality, and its likelihood of completion than potential house buyers. The developer does not share this knowledge about the project's financial stability and construction quality with prospective buyers. The developer faces the trade-off of accepting a lower offer to reduce time-on-market, generate cash flow, and reduce carrying costs, or to hold out for a higher price while enduring longer TOM.
Buyers incur more risk by purchasing units early in the presale process. The risk of default by the developer is highest when few units have been sold and little capital has been invested in the project. As construction proceeds, the risk of the developer abandoning the project declines. The potential buyer also can see limited tangible evidence that the buildings are progressing toward completion and delivery for occupation, which reduces information asymmetry. In addition, changes in market conditions and housing prices are less likely to occur when the time period between purchase and occupation is short. The opportunity cost of investing in a condominium that is not available for occupancy also declines over time. All these factors should contribute toward buyers moving more quickly to purchase units in later phases of a development. On the other hand, the limited number of units that occupy preferred locations and provide the combination of attributes a consumer wants would encourage buyers to purchase before someone else does. In addition, expectations of rising prices will encourage buyers to buy early to lock in prices. The risk of rising prices is especially true in markets that have historically experienced upward price trends and those in which presale contracts imply a long construction period over which substantial market price increases may occur.

Previous studies of TOM have focused on the resale of single-family houses; however, the presale approach to condominium marketing is common in many Asian cities. This study examines the pattern of TOM for condominium units offered for presale in several phases of a single large homogeneous development in Chengdu, China. We find that longer TOM is associated with a price premium, consistent with most studies of resale houses. Evidence suggests that units offered to the market in early phases in the development take longer to sell than similar units in later phases. In addition, the unit's physical characteristics (unit size and orientation as well as the height of the building) and economic conditions influence TOM. The faster sale of smaller units points to the affordability problem many Chinese homebuyers face. Developers may want to propose and regulators accept proposals for housing projects with a larger proportion of small units to offer more affordable condominiums that would sell more quickly than larger units. The faster sales of units in midrise buildings, but at a lower price, indicates a trade-off that the developer must evaluate. While the sales may take longer, the higher price units in a high-rise command may offset the longer marketing time.

The evidence indicates that condominium sales occur as expected in a presale arrangement in which information asymmetry creates substantial risk. Units sell more slowly in the first phase of a homogeneous development. The developer has relatively little capital invested in the project; there is no physical product for the buyers to see. Thus, despite regulations requiring third-party supervision of construction, buyers are slow to pay full purchase price early in the presale market. This indicates that the current government regulations may be insufficient to create 
a sense of security among presale buyers. Media reports of defaults and defects appear to have made buyers reluctant to purchase units in the first phases of a new development even from a developer with no history of default. Successful developers may need to communicate better with potential buyers to distinguish their companies from their less reputable competitors to speed sale of their units.

As time goes by and new phases are introduced, buyers respond more quickly to the offerings. Information asymmetry has been reduced and, thereby, the risks associated with presale. In addition, the holding period before occupancy is reduced. Holding costs appear to be an important consideration for buyers in presale arrangements. The majority of buyers make a down payment and take out a mortgage from a third party with repayment beginning immediately. Buyers are reluctant to make payments on a unit that they cannot occupy especially if the interest rate is high. They will try to time their purchase close to the project's delivery.

The change in TOM can be accelerated or moderated by market conditions such as mortgage interest rates. Our results show that rising house prices and rising interest rates are associated with longer TOM and that the developer is more likely to obtain a price premium with longer TOM, which indicate that the developer is holding out for expected and realized higher prices while not being constrained by the cost of debt. Meanwhile, buyers are trying to time their purchase to obtain a lower price and lower interest rate. We not see buyers trying to lock in prices early in an environment where prices have generally been rising and the sensitivity to interest rates highlight the housing affordability problem. Since the end of 2015, the Chinese government has expressed concern about the high inventory of unsold houses. Interventions to slow price growth and lower interest rates may be necessary to improve affordability and lower inventory.

Because the data in this study reflect sales over a 20-month period, marketing duration only during the growth phase of the real estate cycle is observed. Further research is necessary to determine whether the relationships hold throughout the other phases of the cycle. When prices are declining, the developer and buyers may respond differently with developers being impatient to sell and buyers holding out for lower prices. Declining prices would increase the risk of developer default.

In addition, to limit the heterogeneity of the condominiums and control for neighbourhood variables, this study employs presale data from only one large subdivision in Chengdu. Because the developer of this project has never experienced default, the analysis cannot evaluate the relative price and TOM adjustments that may occur due to differential default risk based on historical experience.

\section{Acknowledgement}

Funding for the first author for this research was provided by the China Scholarship Council.

\section{References}

Akerlof, G. A. (1970). The market for "lemons": quality uncertainty and the market mechanism. Quarterly Journal of Economics, 84(3), 488-500. https://doi.org/10.2307/1879431

An, Z., Cheng, P., Lin, Z., \& Liu, Y. (2013). How do market conditions impact price-TOM relationship? Evidence from real estate owned (REO) sales. Journal of Housing Economics, 22(3), 250-263. https://doi.org/10.1016/j.jhe.2013.07.003

Asabere, P. K., \& Huffman, F. E. (1993). Price concessions, time on market, and the actual sale price of homes. Journal of Real Estate Finance and Economics, 6(2), 167-174. https://doi.org/10.1007/BF01097024

Belkin, J., Hempel, D. J., \& McLeavey, D. W. (1976). An empirical study of time on market using multidimensional segmentation of housing markets. AREUEA Journal, 4(2), 57-75. https://doi.org/10.1111/1540-6229.00156

Benefield, J. D., Cain, C. L., \& Johnson, K. H. (2014). A review of literature utilizing simultaneous modeling techniques for property price and time-on-market. Journal of Real Estate Literature, 22(2), 149-175.

Chan, S. H., Fang, F., \& Yang, J. (2008). Presales, financing constraints, and developers' production decisions. Journal of Real Estate Research, 30(3), 345-375.

Chan, S. H., Fang, F., \& Yang, J. (2014). Presales, leverage decisions, and risk shifting. Journal of Real Estate Research, 36(4), 457-509.

Chan, S. H., Wang, K., \& Yang, J. (2012). Presale contract and its embedded default and abandonment options. Journal of Real Estate Finance and Economics, 44(1), 116-152. https://doi.org/10.1007/s11146-010-9289-5

Chau, K. W., Wong, S. K., \& Yiu, C. Y. (2003). Price discovery function of forward contracts in the real estate market: an empirical test. Journal of Financial Management of Property and Construction, 8(3), 129-137.

Chau, K. W., Wong, S. K., \& Yiu, C. Y. (2007). Housing quality in the forward contracts market. Journal of Real Estate Finance and Economics, 34(3), 313-325. https://doi.org/10.1007/s11146-007-9018-X

Choi, J., Rasmussen, H., \& Davison, M. (2012). Fair value and risk profiles for presale contracts of condominiums. Journal of Real Estate Finance and Economics, 44(4), 472-504. https://doi.org/10.1007/s11146-010-9248-1

Cox, D. R. (1972). Regression models and life-tables (with discussion). Journal of Royal Statistical Society, B34(2), 187-220.

Cubbin, J. (1974). Price, quality and selling time in the housing market. Applied Economics, 6, 171-187. https://doi.org/10.1080/00036847400000017

Deng, G., Li, Z., \& Ye, G. (2012). Mortgage rate and the choice of mortgage length: quasi-experimental evidence from Chinese transaction-level data. Working Paper 12/02. Hong Kong: BBVA Research.

Deng, Y., \& Liu, P. (2009). Mortgage prepayment and default behaviour with embedded forward contract risks in China's housing market. Journal of Real Estate Finance and Economics, 38(3), 214-240. https://doi.org/10.1007/s11146-008-9151-1

Edelstein, R., Liu, P., \& Wu, F. (2012). The market for real estate presales: a theoretical approach. Journal of Real Estate Finance and Economics, 45(1), 30-48. https://doi.org/10.1007/s11146-011-9318-z

Fan, G.-Z., Pu, M., \& Ong, S. E. (2012). Optimal portfolio choices, house risk hedging and the pricing of forward house transactions. Journal of Real Estate Finance and Economics, 45(1), 3-29. https://doi.org/10.1007/s11146-011-9323-2 
Farrell, L. M. (2003). Principal-agency risk in project finance. International Journal of Project Management, 21(8), 547-561. https://doi.org/10.1016/S0263-7863(02)00086-8

Gustavsson, F., \& Vahtola, S. (2014). Pricing strategies in newly developed housing projects (Master's thesis). Stockholm: KTH Royal Institute of Technology.

Gwin, C. R., \& Ong, S. E. (2000). Homeowner warranties and building codes. Journal of Property Investment and Finance, 28(4), 456-472.

https://doi.org/10.1108/14635780010345409

Han, L., \& Strange, W. (2015). The microstructure of housing markets. In G. Duranton, J. V. Henderson, W. Strange (Eds.), Handbook of regional and urban economics (pp. 813-886). Vol. 5. Amsterdam: Elsevier. https://doi.org/10.1016/B978-0-444-59531-7.00013-2

Haurin, D. (1988). The duration of marketing time of residential housing. AREUEA Journal, 16(4), 396-410. https://doi.org/10.1111/1540-6229.00463

Holmstrom, B. (1979). Moral hazard and observability. Bell Journal of Economics, 10(1), 74-91.

https://doi.org/10.2307/3003320

Hua, C. C., Chang, C. O., \& Hsieh, C. (2001). The price-volume relationships between the existing and the pre-sales housing markets in Taiwan. International Real Estate Review, 4(1), $80-94$.

Hui, E. C. M., Wong, J. T. Y., \& Wong, K. T. (2012). Marketing time and pricing strategies. Journal of Real Estate Research, 34(3), 375-398.

Hui, E. C. M., \& Yu, K. H. (2012). The impact of pricing strategies on time-on-market under various economic conditions. International Journal of Strategic Property Management, 16(1), 56-70. https://doi.org/10.3846/1648715X.2011.585185

Hwang, M., \& Quigley, J. (2010). Housing price dynamics in time and space: predictability, liquidity and investor returns. Journal of Real Estate Finance and Economics, 41(1), 3-23. https://doi.org/10.1007/s11146-009-9207-x

Kalra, R., \& Chan, K. C. (1994). Censored sample bias, macroeconomic factors and time on market of residential housing. Journal of Real Estate Research, 9(2), 253-262.

Kang, H. B., \& Gardner, M. J. (1989). Selling price and marketing time in the residential real estate market. Journal of Real Estate Research, 4(1), 21-35.

Lai, R. N., Wang, K., \& Zhou, Y. (2004). Sale before completion of development: pricing and strategy. Real Estate Economics, 32(2), 329-357.

https://doi.org/10.1111/j.1080-8620.2004.00094.x

Leland, H. E., \& Pyle, D. H. (1977). Informational asymmetries, financial structure, and financial intermediation. Journal of Finance, 32(2), 371-387. https://doi.org/10.2307/2326770

Leung, B. Y. P., Hui, E. C. M., \& Seabrooke, B. (2007a). Asymmetric information in the Hong Kong forward property market. International Journal of Strategic Property Management, 11(2), 91-106.

Leung, B., Hui, E., \& Seabrooke, B. (2007b). Pricing of presale properties with asymmetric information problems. Journal of Real Estate Portfolio Management, 13(2), 139-152.
Li, W.-F. (2004). The impact of pricing on time-on-market in high-rise multiple-unit residential developments. Pacific Rim Property Research Journal, 10(3), 305-327.

https://doi.org/10.1080/14445921.2004.11104165

Liu, Y. (2007). Buyers demand compensation. Group of 30 owners at Chongqing villa project complain of poor quality at Cheung Kong and Hutchison development, South China Morning Post. Retrieved from http://www.scmp.com/article/581087/buyers-demand-compensation

Miller, N. M., Sklarz, M., \& Ordway, N. (1988). Japanese purchases, exchange rates and speculation in residential real estate markets. Journal of Real Estate Research, 3(3), 39-49.

National Bureau of Statistics of China. (2011). China statistical yearbook. Beijing: China Statistics Press.

Ong, S. E. (1997). Building defects, warranties and project financing from pre-completion marketing. Journal of Property Finance, 8(1), 35-51. https://doi.org/10.1108/09588689710160507

Ong, S. E. (1999). Caveat emptor: adverse selection in buying properties under construction. Property Management, 17(1), 49-64. https://doi.org/10.1108/02637479910255749

Ong, S. E., \& Koh, Y. C. (2000). Time-on-market and price tradeoffs in high-rise housing sub-markets. Urban Studies, 37(11), 2057-2071. https://doi.org/10.1080/713707223

Sirmans, G. S., MacDonald, L., \& Macpherson, D. (2010). A meta-analysis of selling price and time-on-the-market. Journal of Housing Research, 19(2), 130-152.

Waller, B. D., Brastow, R., \& Johnson, K. H. (2010). Listing contract length and time on market. Journal of Real Estate Research, 32(3), 271-288.

Wong, S. K., Chau, K. W., Yau, Y., \& Cheung, A. K. C. (2011). Property price gradients: the vertical dimension. Journal of Housing and the Built Environment, 26(1), 33-45. https://doi.org/10.1007/s10901-010-9203-8

Wong, S. K., Yiu, C. Y., Tse, M. K. S., \& Chau, K. W. (2006). Do the forward sales of real estate stabilize spot prices?. Journal of Real Estate Finance and Economics, 32(3), 289-304. https://doi.org/10.1007/s11146-006-6803-X

Wu, J., Deng, Y., \& Liu, H. (2014). House price index construction in the nascent housing market: the case of China. Journal of Real Estate Finance and Economics, 48(3), 522-545. https://doi.org/10.1007/s11146-013-9416-1

Yang, Z. (2001). An application of the hedonic price model with uncertain attribute: the case of the People's Republic of China. Property Management, 19(1), 50-63. https://doi.org/10.1108/02637470110366202

Yiu, C. Y., Hui, E. C. M., \& Wong, S. K. (2005). Lead-lag relationship between the real estate spot and forward contracts markets. Journal of Real Estate Portfolio Management, 11(3), 253-262.

Yiu, C. Y., Wong, S. K., \& Chau, K. W. (2009). Transaction volume and price dispersion in the presale and spot real estate markets. Journal of Real Estate Finance and Economics, 38(3), 241-253. https://doi.org/10.1007/s11146-008-9161-Z

Zhou, X., Zahirovic-Herbert, V., \& Gibler, K. M. (2015). Asymmetric buyer information influence on price in a homogeneous housing market. Urban Studies, 52(5), 801-905. https://doi.org/10.1177/0042098014529464 